\title{
MEMBACA AKTIVISME POLITIK ISLAM DAN DEMOKRASI DI INDONESIA PASCA 212
}

\section{Muhammad Naufan Rizqullah}

Universitas Indonesia, Jakarta, Indonesia

Email: m.naufan1993@gmail.com

\begin{tabular}{l}
\hline INFO ARTIKEL \\
\hline Diterima \\
5 April 2021 \\
Direvisi \\
10 April 2021 \\
Disetujui \\
15 April 2021 \\
\hline
\end{tabular}

Keywords:

radical; islamic political activism; cultural analysis; illiberal analysis; oligarchy \begin{abstract} In the relationship of Islam and democracy, or Islam and politics in general, Indonesia is well-worded both in the post-authoritarian period of the New Order. Until the time of the action on December 2, 2016 (read: Bela Islam Action 212) figures of a tolerant and democratic political order. The culprit is often interpreted as the beginning of Islamic political activism in Indonesia. Belanding from his beliefs, the country's response by means of illiberal intentions as an effort to spread islamic understanding. The political formulation is an array of cultural or ideological concerns about Islam. The formulation of such a policy is based on cultural or ideological arguments about Islam. Opinions are voiced continuously by most Indonesian Islamic intellectuals. The analysis not only sided with issues of human rights and democracy in the name of stability of the country, but also did not provide room for possible power relations and maneuvers among the oligarchs who accompanied them in their interests to influence and control the political arena. Therefore, event 212 is not automatically a manifestation of the cultiation of Islamic political activism or the victory of radical Islam that could jeopardize the existence of Pancasila, the 1945 Constitution, and the Republic of Indonesia, but the phenomenon can be interpreted as an articulation on the issue of social injustice. Such economic-political analysis is necessary to better understand the ongoing dynamics of contemporary religious politics in Indonesia
\end{abstract}

\begin{abstract}
ABSTRAK
Dalam hubungan Islam dan demokrasi, atau Islam dan politik secara umum, Indonesia dipandang berhasil merawat keduanya secara berdampingan dalam masa transisi pasca-otoritarianisme Orde Baru. Sampai ketika aksi yang berlangsung pada 2 Desember 2016 (baca: Aksi Bela Islam 212) dinilai mengancam tatanan politik
\end{abstract}

\begin{tabular}{ll}
\hline How to cite: & Rizqullah, Muhammad Naufan (2021) Membaca Aktivisme Politik Islam Dan Demokrasi Di \\
& Indonesia Pasca 212. Jurnal Syntax Admiration 2(4). https://doi.org/10.46799/jsa.v2i4.215 \\
E-ISSN: & $\frac{2722-5356}{\text { Ridwan Institute }}$
\end{tabular}


Kata kunci:

radikalisme; aktivisme politik islam; analisis kultural; kebijakan illiberal; oligarki yang toleran dan demokratis. Peristiwa tersebut kerap dimaknai sebagai awal kebangkitan aktivisme politik Islam di Indonesia. Berangkat dari keyakinan tersebut, respon negara adalah dengan memberlakukan kebijakan illiberal sebagai upaya meredam penyebaran paham radikalisme Islam. Formulasi kebijakan semacam itu disusun berdasarkan argumen kultural atau ideologi tentang Islam. Opini yang disuarakan secara terusmenerus oleh kebanyakan intelektual Islam Indonesia. Analisis yang bukan hanya menyampingkan isu tentang hak asasi dan demokrasi atas nama stabilitas negeri, melainkan juga tidak memberikan ruang kemungkinan terjadinya relasi kuasa dan manuver di antara oligarki yang menyertainya dalam kepentingannya memengaruhi dan menguasai arena politik. Oleh karena itu, peristiwa 212 tidak secara otomatis merupakan manifestasi dari kulminasi aktivisme politik Islam atau kemenangan Islam radikal yang dapat membahayakan eksistensi Pancasila, UUD 1945, dan NKRI, tetapi fenomena tersebut dapat dimaknai sebagai artikulator tentang isu ketidakadilan sosial. Analisis ekonomi-politik semacam itu diperlukan guna memahami lebih luas dinamika politik keagamaan kontemporer yang sedang berlangsung di Indonesia.

\section{Pendahuluan}

Peristiwa pilkada DKI Jakarta 2017 dianggap oleh banyak kalangan sebagai awal kemunculan populisme Islam. Mobilisasi politik identitas dan intoleransi dinilai sebagai ancaman politik, bahkan menjadi momok yang memecah belah persatuan bangsa. Menguatnya artikulasi kebencian dan rasialisme yang diucapkan secara massal dalam momen tersebut turut menyumbang kemunduran demokrasi di Indonesia. Menurut Dirk Tomsa, pudarnya demokrasi dan hak asasi manusia di era pemerintahan Joko Widodo ditandai dengan, salah satunya, intoleransi yang menguat, terutama yang dimobilisasi di sepanjang masa kampanye pemilihan gubernur DKI Jakarta 2017 (Tomsa, 2017).

Namun, gejala intoleransi tersebut justru ditanggapi pemerintahan Joko Widodo dengan mengambil kebijakan-kebijakan illiberal yang membahayakan demokrasi. Pasca aksi 212, proponen kelompok tersebut dipidana, organisasi Hizbut Tahrir Indonesia (HTI) dilarang tanpa melalui mekanisme pengadilan, serta sejumlah kegiatan kelompok \#2019GantiPresiden menjelang pemilihan presiden 2019 dihambat. Respon "politik keamanan" berbasis narasi ancaman radikalisme semacam itu pada akhirnya juga mereduksi hak-hak sipil dan politik kelompok-kelompok kritis lainnya yang mempertanyakan kebijakan negara terkait misalnya, isu pemberantasan korupsi dan pelestarian lingkungan hidup (Tomsa, 2017).

Narasi bahaya radikalisme Islam semakin direproduksi pemerintahan Joko Widodo. Marcus Mietzner melihat kecenderungan itu sebagai strategi rezim untuk merepresi sekaligus mengakomodasi aktivisme politik Islam pasca momen 212. 
Merepresi didasarkan pada penciptaan dan pemberlakuan seperangkat peraturan yang memungkinkan pelarangan dan pembubaran terhadap organisasi yang dinilai bertentangan dengan Pancasila. Respon ini ditujukan untuk mereka yang distigmatisasi sebagai kelompok "Islam radikal-khilafah". Sementara itu, akomodasi diberikan kepada kekuatan-kekuatan politik yang bersedia mengikuti dan mematuhi rezim. Respon ini ditujukan untuk mereka yang dipandang sebagai kelompok "Islam toleran-nasionalis". Formulasi tersebut mengakibatkan radikalisme agama dan hiper-nasionalisme menjadi santapan harian masyarakat yang justru kian terbelah menjadi dua "kue" sederhana yang sama-sama cenderung bercorak illiberal. Artinya, hak asasi dan penguatan demokrasi makin tereksklusi dari percakapan publik mengenai politik Indonesia. Dengan demikian, Indonesia tengah memasuki apa yang disebut Mietzner sebagai dekonsolidasi demokrasi (Mietzner, 2018).

Negara kerap menempatkan pemahaman radikal beragama secara terpisah dari problem sosial yang terkait dengannya. Perspektif itu memfasilitasi kulturalisasi konflik sosial yang termanifestasikan dalam, meminjam istilah Bernard Lewis, "Muslim moderat" versus "Muslim radikal" (Lewis, 2014). Namun, pada saat yang bersamaan, artikulasi-artikulasi politiknya seperti tuntutan atas keadilan sosial dan redistribusi tidak mendapatkan perhatian memadai dari pemerintah. Dengan kata lain, negara acap kali memandang dinamika radikalisme Islam secara "tersendiri" di luar arena pertarungan sosial dalam proses ekonomi-politik yang telah berlangsung lama dan menyejarah. Pada akhirnya, pembacaan semacam itu ikut mendorong pemerintah untuk memberi perhatian khusus terhadap fenomena populisme Islam, yang dinilai sebagai sumber dari pelbagai persoalan di negeri ini. Tulisan ini mencoba menguraikan bahwa pengarusutamaan pendekatan kultural atau ideologi dalam memahami meningkatnya aktivisme politik Islam berimplikasi pada merosotnya demokrasi di Indonesia. Sebab salah satu indikasi dari kecenderungan demokrasi illiberal terjadi adalah adanya represi terhadap kekuatan Islamisme melalui maraknya promosi wacana radikalisme.

\section{Metode Penelitian}

Penelitian ini menggunakan penelitian kualitatif dengan menggunakan analisis eksplorasi. Penelitian kualitatif merupakan suatu bentuk inkuiri interpretatif, di mana peneliti membuat interpretasi atas apa yang mereka lihat, dengar, dan pahami. Strategi dalam melakukan penelitian kualitatif adalah dengan memfokuskan pada pengumpulan data, analisis, dan penulis (Labolo et al., 2020). Mengingat penelitian ini akan membahas tentang aktivisme Islam dan kondisi demokrasi pasca 212, maka pendekatan penelitian kualitatif dapat dikatakan tepat untuk mengungkap permasalahan penelitian.

Penulis menggunakan bentuk penelitian pustaka (library research), di mana peneliti mengamati objek penelitian melalui bahan pustaka berupa buku, jurnal, laporan penelitian sebelumnya, dan media internet (Labolo et al., 2020). Sedangkan data yang digunakan untuk menganalisis permasalahan diatas diantaranya: berita-berita terkait isu di atas serta beberapa penelitian terdahulu. 


\section{Hasil dan Pembahasan}

A. Radikalisme Islam dan Demokrasi Indonesia Pasca 212

Indonesia seringkali dipandang sebagai contoh keberhasilan bagi hubungan antara agama dan negara atau Islam dan demokrasi. Fenomena intoleransi dan politik identitas dalam praktik demokrasi dewasa ini memang menjadi problem. Kekhawatiran atas praktik demokrasi dan intoleransi itu dipicu oleh mobilisasi massa dan penggunaan narasi serta penanda-penanda Islam untuk mengalahkan calon gubernur petahana yang beragama Kristen dan beretnis Cina, Basuki Tjahaja Purnama (Ahok), dalam Pilkada DKI Jakarta 2017. Aksi demonstrasi damai dengan jumlah massa terbesar sepanjang sejarah politik Indonesia pada 2 Desember 2016 itu memang menjadi fenomena yang mengejutkan publik dan menciptakan polarisasi dalam masyarakat. Sebagian masyarakat menganggap kekalahan Ahok dalam pilkada dan pemidanaan dirinya atas tuduhan penistaan agama sebagai kemenangan Islam radikal sekaligus bentuk konkret dari ancaman radikalisme Islam.

Dalam literatur hubungan Islam dan politik, pandangan seperti itu mewakili perspektif esensialis yang memandang sumber persoalannya pada agama dan penafsiran atas teks. Agama sebagai sebuah esensi dari ideologi dan kultur yang sudah tetap dan tidak berubah. Perspektif ini kurang mempertimbangkan analisis relasi kuasa ketika menjelaskan Islam politik beserta dinamika sosialnya dalam konteks historis yang spesifik dikarenakan ia mengutamakan ideologi dan kultur sebagai penjelasannya. Konsekuensinya, pandangan tersebut gagal membongkar konstelasi kekuasaan yang menjadikan Islam justru sebagai objek disiplin dan intervensi aktor-aktor kekuasaan.

Jenderal (Purn) Wiranto saat menjabat sebagai Menkopolhukam pernah menyatakan kelompok Aksi 212 merupakan sebuah ancaman untuk pembangunan nasional. "Paling tidak kita bisa sampaikan bahwa peristiwa yang dikenal 411, 212, atau terorisme, (sengketa) pilkada serentak, pemilu serentak terkait dengan kasus 2122 Mei, ini sebenarnya suatu bagian dari ancaman, gangguan, dan hambatan dalam rangka pembangunan nasional yang telah dilakukan pemerintah di bawah Presiden Joko Widodo" (Robingatun, 2017). Menkopolhukam dapat dikatakan sebagai representasi pemerintah dalam memaknai pelbagai peristiwa politik yang tengah berlangsung. Sebagaimana telah sedikit dijelaskan sebelumnya, kebijakan politik yang diambil pemerintah pasca-momen 212 bertendensi mengabaikan prinsip-prinsip politik liberal, seperti jaminan negara atas kebebasan berpendapat ataupun perlindungan atas hak-hak sipil dan politik. Pasca 212, narasi isu radikalisme sebagai ancaman bagi kehidupan berbangsa kian masif.

Nada serupa juga terdengar sama ketika pemerintah membubarkan HTI. Melalui Peraturan Pemerintah Pengganti Undang-Undang Nomor 2 Tahun 2017, HTI dicabut status badan hukumnya dengan alasan karena HTI tidak melaksanakan peran positif untuk mengambil bagian dalam proses pembangunan nasional guna mencapai tujuan nasional, kegiatan yang dilaksanakan HTI terindikasi kuat telah bertentangan dengan tujuan, azas, dan ciri yang berdasarkan Pancasila dan UUD 1945, serta 
aktivitas HTI dinilai telah menimbulkan benturan di masyarakat yang dapat mengancam keamanan dan ketertiban masyarakat serta membahayakan keutuhan NKRI (Movanita, 2017). Ekspresi politik Islam yang dianggap berseberangan dengan kepentingan negara cenderung mendapat sorotan tajam dari pemerintah. Alhasil, beberapa kalangan menyebut ruang kebebasan sipil di Indonesia selama periode pemerintahan Joko Widodo semakin menyempit (shrinking space) (Nasution, 2020). Laporan freedom house menunjukkan adanya kemerosotan kebebasan di Indonesia dan status kebebasan di Indonesia diturunkan dari bebas menjadi bebas sebagian (House, 2017).

Pemerintah juga menyoroti dengan tajam mengenai beredarnya tagar \#2019GantiPresiden pada saat menjelang Pemilu Presiden 2019. Menteri Koordinator Bidang Kemaritiman Luhut Binsar Pandjaitan misalnya, mengatakan bahwa kegiatan \#2019GantiPresiden mesti dilarang (Power, 2018). Komentar salah satu pejabat pemerintahan tersebut bisa dikatakan juga menciderai nilai-nilai demokrasi liberal karena tidak sejalan dengan nilai-nilai kebebasan berpendapat dalam kaidah demokrasi. Di samping itu, sebagian masyarakat sipil yang menolak gerakan \#2019GantiPresiden juga ditopang dengan perspektif kultural yang meyakini radikalisme keagamaan berada di balik aktivisme politik Islam dalam tubuh gerakan tersebut. M. Najih Arromadloni, misalnya, mengidentifikasi kelompok \#2019GantiPresiden memiliki kesamaan misi dengan kelompok oposisi keagamaan Suriah bernama Jabhat Al-Nusra yang ingin menjatuhkan Presiden Suriah Bashar AlAssad, yang berujung pada konflik sosial dan krisis politik berkepanjangan (Arromadloni, 2016). Pembingkaian narasi radikalisme Islam semacam itu terhadap mereka yang berada di belakang gerakan \#2019GantiPresiden terus direproduksi negara bersamaan dengan pemberian label "Islam moderat" pada mereka yang mendukung pemerintah. Padahal, pengarusutamaan Islam moderat itu sendiri lebih sering didefinisikan secara esensialis melalui kategori-kategori kultural atau ideologis.

Analisis dengan menggunakan pandangan kultural yang cenderung bertentangan dengan nilai-nilai demokrasi dalam menyikapi kegiatan yang dianggap sebagai gerakan Islam radikal juga terlihat dari analisis berbagai tokoh masyarakat. Pandangan kultural dalam melihat problem radikalisme Islam, misalnya, diutarakan Ketua Umum PBNU Said Aqil Siradj yang bertendensi "menyalahkan" kebebasan berpendapat di media sosial sebagai sarana tumbuh dan berkembangnya paham radikal dalam beragama yang mengoyak toleransi dan merusak keutuhan bangsa. Atas dasar itu, ia meminta pemerintah untuk bersikap tegas terkait isu radikalisme (Usman et al., 2014). Perspektif serupa dikemukakan Azyumardi Azra, intelektual Islam, dalam artikelnya berjudul "Demokrasi Mau ke Mana?". Ia mendukung langkah pemerintah dalam menerbitkan Perppu No. 2 Tahun 2017 tentang Organisasi Kemasyarakatan dan ia meyakini hadirnya produk hukum tersebut bukan merupakan faktor yang membuat demokrasi di Indonesia mengalami kemunduran. Menurut Azra, perpu tersebut adalah perpu anti-radikalisme (Azra, 2016). 
Narasi semacam itu cenderung "membaca" kelompok Islam radikal dalam dirinya sendiri sudah bertentangan dengan demokrasi. Oleh karena itu, keharusan menumpas sampai ke akar-akarnya adalah cara efektif untuk meredamnya. Analisis seperti itu memberi peluang untuk lahirnya kembali pemerintahan yang represif, yang didasari atas asumsi bahwa tumbuh suburnya radikalisme Islam akibat negara dalam proses demokratisasinya tidak berhasil menghadirkan keamanan dan ketertiban umum. Padahal, aktivisme politik Islam yang beragam tak terkecuali juga kaum "Islam moderat" justru mendapatkan ruang artikulasinya yang luas setelah tumbangnya rezim otoritarianisme Orde Baru melalui agenda demokratisasi.

Azyumardi Azra dalam artikelnya yang lain menerangkan bahwa iklim liberalisasi politik dan demokratisasi pasca-reformasi memberi ruang bagi kehadiran dan pertumbuhan Islam bercorak radikal setelah selama 32 tahun ditindas rezim otoritarianisme Orde Baru. Islam radikal merupakan minoritas Islam di tengah watak Islam di Indonesia yang toleran, ramah, akomodatif, dan tidak terlalu terarabisasi. Sehingga, karakter Islam di Indonesia cenderung kurang rigid sebagaimana ekspresi keislaman di Timur Tengah. Sama seperti arus-utama kajian kultural pada umumnya, Azra lebih mengedepankan problem Islam radikal pada pemahaman mereka yang literalis dan tekstualis sebagai akar persoalannya. Ia kurang menguraikan secara lebih detail faktor penyebab kemunculan kelompok Islam radikal yang menurut banyak kalangan tidak bisa dilepaskan dari kepentingan politik para jenderal Orde Baru.

Apa yang diterangkan Said Aqil Siradj dan Azyumardi Azra di atas bahwa proses keterbukaan politik pasca-Orde Baru justru memunculkan konfrontasi dan konflik di antara arus-utama Islam moderat dan ramah dengan kelompok Islam radikal yang memaknai ajaran Islam secara literal dan kaku. Tak ayal persoalan radikalisme terdomestikasi hanya berada "di dalam" masyarakat muslim itu sendiri yang termanifestasikan. Menurut Mahmood Mamdani, "Muslim baik" melawan "Muslim buruk" (Muslim \& Muslim, 2013). Model artikulasi itu memfasilitasi kulturalisasi Islam politik dengan memberi penegasan kembali kategori-kategori biner: radikal dan moderat. Problem dari perspektif semacam itu cenderung akan kehilangan fokus pada gambaran makro sosiologis tentang peran dan posisi kekuatan Islam politik dalam hubungannya dengan pembangunan negara dan struktur ekonomi-politik yang menyejarah. Pemahaman kultural atau ideologis seperti itu bertendensi melihat kontestasi yang berlangsung semata-mata sebagai hasil dari pembacaan teks dalam pengalaman budaya umat Islam. Bukan sebaliknya bahwa kebangkitan kekuatan Islamisme adalah akibat dari pertarungan sosial. Lebih jauh, analisis kultural minim mencari adanya keterkaitan antara kelompok Islam radikal dan kekuatan elite politik-bisnis yang memengaruhi konstelasi sosial dalam pertarungan memperebutkan kekuasaan dan sumber daya publik.

Penjelasan akademik atas fenomena radikalisme Islam seperti itu rutin bertaut dengan kepentingan aktor-aktor politik mapan yang tengah mendominasi negara untuk melanggengkan kekuasaan dengan mengapitalisasi wacana bahaya radikalisme dan menggunakannya untuk merepresi kekuatan-kekuatan sosial yang berpotensi 
menjadi oposan dari kekuasaan. David Price menjelaskan bahwa produksi pelbagai narasi pengetahuan tentang radikalisme Islam memiliki fungsi ganda. Pada satu sisi bertujuan melayani pencarian pengetahuan sejati tentang kondisi dan realitas sosial yang ada. Namun, disisi lain, konteks politik yang berlangsung saat ini bisa dimanfaatkan untuk melayani urusan strategis instrumentalis kepentingan kekuasaan yang menjadikan radikalisme sebagai masalah dan ancaman utama terhadap kehidupan berbangsa sembari menyampingkan persoalan-persoalan politik lainnya terkait ketimpangan kekuasaan dan sosial (Price, 2016).

Dengan demikian, bisa dikatakan bahwa negara dan pemerintah terjebak dalam

pendekatan kultural dalam menganalisa problem Islam radikal dan mengenyampingkan faktor-faktor lain. Sementara itu, karena problemnya di lokalisasi semata tentang Vis a Vis antara yang pluralis-toleran dan yang radikalintoleran, yang dianggap memiliki essence ideologi yang tepat dalam hubungan yang bersifat saling antagonistik di antara keduanya, mereka yang melihat radikalisme melalui lensa kultural juga dimungkinkan untuk "diuntungkan" sekalipun pendekatan negara untuk meredam mereka yang distigmatisasi masuk kategori Islam radikal menggunakan cara-cara illiberal. Keduanya, para penganut pendekatan kultural maupun elite politik anti-demokratik warisan Orde Baru di dalam struktur kekuasaan negara, menganggap strategi "politik keamanan" dengan membatasi ruang liberalisasi politik menjadi prasyarat utama untuk menghadapi radikalisme sekaligus menjaga "keamanan" negara.

Argumen para pengusung pendekatan kultural yang melihat radikalisme Islam tumbuh dalam ruang yang bebas dari kegaduhan konflik sosial di antara aliansialiansi oligarki beserta kepentingannya di dalamnya memberi kemudahan bagi kelompok dominan dalam negara untuk menemukan "sumber persoalan" bangsa dalam subjek yang dinilai sebagai bagian dari kelompok radikal. Perspektif tersebut juga dengan sendirinya menghindari bahkan mengabaikan ruang analisis bagi hadirnya manuver para oligarki yang menguasai arena politik sebagai masalah utama kekuasaan di Indonesia. Karena oligarki kerap menghambat upaya pendistribusian keadilan dan negara tidak mampu mendatangkan kemakmuran, maka isu stabilitas diambil dan terus digencarkan.

\section{B. Artikulasi Islam Politik dan Intervensi Oligarki}

Tampil dan menguatnya aktivisme politik Islam setelah peristiwa 212 dapat dilihat sebagai bagian dari ekspresi keagamaan dalam memaknai realitas sosial yang terjadi di masyarakat. Di tengah absennya pelbagai alternatif politik yang kredibel, wacana politik keagamaan tampil sebagai artikulator utama kelompok-kelompok yang mengalami marginalisasi dalam proses demokrasi dan pembangunan. Memahami politik Islam menjadi perlu untuk ditempatkan dalam analisis sosiologis yang mengaitkan agama dengan konteks sosial yang lebih luas. Tepat di titik itu, pendekatan kultural mendapatkan kritik. 
Menurut (Mudhoffir et al., 2017), fenomena radikalisme Islam merupakan sebuah epifenomena (gejala sosial yang terhubung dengan kondisi sosial yang lebih mendasar) dari permasalahan sosial yang lebih fundamental. Dalam cara pandang itu, bukan berarti problem intoleransi dan politik identitas tidak ada, tetapi artikulasi massa 212 bisa dipahami sebagai akumulasi kekecewaan atas ketimpangan sosial dan problem struktural yang berlangsung di Indonesia pasca-otoritarianisme Orde Baru. Laporan Credit Suisse pada 2016, misalnya, menunjukkan bahwa 1 persen orang terkaya di Indonesia (sekitar 2,6 juta orang) menguasai sekitar 49 persen atau hampir setengahnya dari total kekayaan Indonesia, sementara 10 persen orang terkaya (26 juta orang) memiliki 77 persen total kemakmuran Indonesia. Sedangkan sebaliknya, hanya 1,4 persen dari total kekayaan aset negara dimiliki 100 juta orang termiskin (40 persen) Indonesia. Kendati angka kemiskinan absolut menurun, dengan menggunakan standar kemiskinan World Bank, 93 juta jiwa (36 persen) penduduk Indonesia masih berada di jurang kemiskinan (Bank, 2016). Selain itu, Asia Development Bank 2014 memperlihatkan bahwa terdapat sekitar 55 persen rumah tangga Indonesia yang terkategorikan kelas menengah terjerembap pada belenggu kemiskinan. Artinya, kelas menengah rentan (precariat middle class) yang mendominasi kelas menengah di Indonesia itu bisa kapan saja kembali jatuh miskin. Kecemasan akan terjadinya kemiskinan sosial di kalangan kelas menengah rentan tersebut patut diperhatikan sehubungan dengan problem politik berbasis identitas. Sebab kelas menengah yang rentan itu potensial menjadi basis sosial dan sumber daya politik bagi para oligarki yang menjalin relasi sekaligus mengkooptasi kekuatan aktivitas Islam.

Dalam diskursus Marxisme, agama menjadi bagian inheren dalam pertarungan di antara kelas-kelas sosial mapan, baik dalam kontestasi kekuasaan format negara maupun perang manuver memperebutkan posisi di dalam masyarakat sipil. Menurut Luqman Nul Hakim, kritik Marxis melalui pembacaan atas agama sebenarnya merupakan pengusutan kritis, yakni mengatasi relasi-relasi sosial di tengah masyarakat yang mengalienasi manusia dari kesadaran dan kemerdekaannya. Alhasil, fenomena Islam politik beserta agensi-agensinya yang memakai sentimen, bahasa, dan simbol agama untuk mengartikulasikan masalah ketimpangan kekuasaan dan keluhan-keluhan ekonomi dapat dimengerti.

Sementara itu, walaupun mampu mengartikulasikan keluhan ketidakadilan sosial, populisme Islam yang muncul juga senantiasa menciptakan antagonisme budaya serta kebencian terhadap paham dan identitas yang berbeda, seperti adanya penolakan terhadap pola keberagaman dan pluralisme sosial, menolak untuk mengakui hak-hak para korban 1965, perlawanan terhadap feminisme dan ekspresi politik progresif kiri yang dianggap sebagai gaya baru komunisme, resistensi terhadap kelompok liberal dan sekuler, serta menolak gagasan kesetaraan antar warga negara (civic citizenship). Karena artikulasi yang tampil mengemuka jadi lebih bersifat sektarian, kalangan aktivisme politik Islam dinilai menghalangi pertumbuhan demokrasi dan hak asasi manusia di Indonesia. Dalam situasi demikian, absennya 
kekuatan dan basis sosial-politik progresif dan liberal di Indonesia, yang terbiasa dan fasih membicarakan penguatan demokrasi membuat kaum Islamisme tidak ditopang kalangan akar rumput progresif dan kelas menengah yang dapat mengartikulasikan isu-isu substantif di ruang publik. Sebab pembicaraan politik di Indonesia belakangan ini didominasi kembali ide tentang keutuhan bangsa, nasionalisme, dan pluralisme yang sesungguhnya didasari atas kebutuhan politik temporal. Wacana radikalisme agama dan hiper-nasionalisme tampil menguat dan cenderung justru menghasilkan blok-blok berbasis komunitarianisme. Alhasil, aliansi organik tersebut jadi tampak lemah dan mengalami kesulitan untuk memengaruhi arena politik dalam pertarungan demokrasi. Alih-alih memperjuangkan agenda keadilan sosial yang lebih inklusif dengan melawan kekuatan mapan oligarki, Islam politik justru sangat rentan di instrumentalisasi kekuatan-kekuatan oligarki yang sedang bertarung memperebutkan kekuasaan.

Berbeda dengan pendekatan kultural yang menempatkan kemunculan Islam politik saat agenda demokratisasi dimulai pasca Orde Baru dan menguat dalam peristiwa 212 beserta praktik-praktik eksklusionernya itu sebagai keberhasilan kelompok Islam radikal dalam membajak demokrasi, pemahaman ekonomi-politik justru memberi penjelasan bahwa fenomena radikalisme Islam di Indonesia tidaklah sebesar yang selama ini digaungkan. Bahkan ia mampu menangkap pelbagai tuntutan kesejahteraan dan perbaikan ekonomi di dalam ekspresi kemarahan kelompok Islam radikal, sekaligus menunjukkan energi tersebut berpotensi dimanfaatkan para oligarki. Oligarkisme semacam itu yang justru membajak demokrasi dan menghasilkan illiberalisme. (Hadiz \& Robison, 2013), mengungkapkan bagaimana oligarki beserta dominasinya memanfaatkan sumber daya politik berupa kekuatan Islamisme serta hiper-nasionalisme sebagai instrumen pendukung mengakibatkan proses demokratisasi di Indonesia berjalan di tempat. Di samping itu, ketiadaan kepentingan aliansi-aliansi oligarki dalam memajukan hak-hak sipil dan politik turut membuat demokrasi di Indonesia bercorak illiberal (Hadiz, 2017). Analisis lain seperti Eve Warburton dan Edward Aspinall juga menyebut, akibat ulah elite politik anti-demokratik, perjalanan demokrasi Indonesia selama beberapa tahun terakhir cenderung menuju demokrasi illiberal berjalan memburuk dari stagnasi menuju regresi (Warburton \& Aspinall, 2017).

Dalam lensa struktural, kekuatan aliansi-aliansi oligarki dapat memengaruhi kelompok Islam radikal. Eksistensi mereka bergantung pada para oligarki yang memanfaatkan mereka sebagai instrumen politik. Sekalipun tampil menguat dan solid, Islam politik tidak memiliki kelas borjuasi Muslim yang kuat, maka untuk mempertahankan eksistensinya di arena politik, mereka perlu menjalin relasi dan negosiasi politik dengan elite politik-bisnis oportunis yang sedang bertarung di antara sesamanya. Dalam pembacaan atas kekalahan Ahok dalam pemilihan gubernur DKI Jakarta 2017, Vedi R. Hadiz, misalnya, melihatnya tidak seperti pendekatan yang menekankan argumen kemenangan Islam radikal, melainkan bahkan sebagai indikasi atas kemampuan para oligarki memobilisasi kekecewaan dan 
mengapitalisasi kerentanan agensi-agensi Islam politik melalui penanda-penanda agama. Dengan demikian, munculnya populisme Islam yang mengancam toleransi tidak terlepas dari pertarungan antar oligarki dalam merebut dan mempertahankan kekuasaan dan kontrol atas sumber daya. Dengan kata lain, perspektif ekonomipolitik lebih berorientasi pada fenomena "politisasi Islam", ketimbang "Islamisasi politik" sebagai keterangan pokok para penganjur pendekatan kultural atau ideologi.

Dalam pandangan ekonomi-politik, aktivisme politik Islam tidak dibatasi pada pembacaan tafsir serta pemahaman keagamaan saja, akan tetapi fenomena tersebut terjadi tidak serta merta bisa dilepaskan dari ketegangan pertarungan sosial dan kontestasi politik dalam relasi kekuasaan beserta pelbagai problem sosial di dalamnya.

Dengan demikian, pembacaan lebih luas atas fenomena Islam politik semacam itu dapat memberi rambu-rambu agar kita terhindar dari penarikan kesimpulan yang terburu-buru, agar rezim pemerintah terhindar dari pengambilan kebijakan yang keliru dengan mengasumsikan ancaman radikalisme Islam secara berlebihan, yang mesti ditangani secara khusus dengan memberi pengecualian pada mereka sebagai warga negara yang tidak memiliki hak atas pemenuhan hak-hak sipil dan politiknya.

\section{Kesimpulan}

Merosotnya demokrasi dan hak asasi manusia pada masa pemerintahan Joko Widodo sebagian besar terjadi akibat tekanan di antara meningkatnya aktivisme politik Islam di satu sisi dan Tindakan represif pemerintah terhadap aktivitas terkait. Tampil dan menguatnya aspirasi Islam politik mendorong tanggapan negara untuk mengedepankan strategi "politik keamanan" yang anti-demokrasi, yang secara ironis justru dipakai sebagai dalih untuk mempertahankan demokrasi. Demokrasi illiberal tersebut bekerja karena ditopang pandangan yang menempatkan radikalisme Islam sebagai sumber pelbagai problem bangsa dan ancaman utama keamanan negara. Narasi bahaya artikulasi Islam dalam arena politik semacam itu juga menempatkan wacana toleransi yang terus direproduksi di kulturalisasi sebagai persoalan moral dan etiket hidup bersama yang terpisah dari problem-problem struktural seperti isu ketimpangan ekonomi dan keadilan sosial. Ketika artikulasi-artikulasi Islam politik didomestikasi dalam isu seputar intoleransi dan stabilitas negeri, problem demokrasi Indonesia dirumuskan sebagai konflik antara arus-utama "Islam toleran-nasionalis" dan minoritas "Islam radikal-khilafah". Dalam situasi demikian, toleransi dan diskursus demokrasi mengandung permasalahan dari dalam dirinya: kekuatan politik dengan diskursus toleransi dan nasionalisme yang kuat di waktu bersamaan juga bisa menjadi kekuatan politik bersama aktor-aktor anti-demokratik yang terlibat di dalam struktur kekuasaan negara untuk membenarkan pelanggaran hak asasi manusia dan melemahkan normanorma demokrasi.

Pembacaan kritis lainnya terhadap fenomena radikalisme Islam serta demokrasi berangkat dari problem mendasar masyarakat yang terus-menerus tereksklusi dari proses pembangunan. Karena ketiadaan saluran politik alternatif, wacana Islam politik 
dipandang mampu menjadi artikulator utama yang lantang menyuarakan pelbagai persoalan di tengah masyarakat terkait ketidakadilan sosial. Bersamaan dengan itu, oligarki kekuasaan sebagai persoalan pokok kekuasaan di Indonesia tidak bisa dilepaskan dari kegaduhan politik belakangan ini terkait fenomena Islam politik. Karena demokrasi tengah mengalami kemunduran, pembacaan alternatif seperti ini menjadi kian penting sebagai upaya membedah peran dan posisi oligarki di dalam praktikpraktik berdemokrasi, yang keberadaan beserta kepentingannya menghapus artikulasi kesetaraan, sebagai salah satu pilar utama ideal demokrasi, dalam wacana-wacana demokratisasi.

\section{BIBLIOGRAFI}

Arromadloni, M. N. (2016). Pemahaman Hadis Di Kalangan Islamic State Of Iraq And 
Syria. Uin Suanan Ampel Surabaya. Google Scholar

Azra, A. (2016). Transformasi Politik Islam: Radikalisme, Khilafatisme, Dan Demokrasi. Kencana. Google Scholar

Bank, W. (2016). Indonesia’s Rising Divide. World Bank. Google Schoolar

Hadiz, V. R. (2017). Behind Indonesia's Illiberal Turn', New Mandala, 20 October. Google Scholar

Hadiz, V. R., \& Robison, R. (2013). The Political Economy Of Oligarchy And The Reorganization Of Power In Indonesia. Indonesia, 96, 35-57. Google Scholar

House, F. (2017). Freedom In The World 2017-Indonesia. Google Scholar

Labolo, M., Rohmansyah, H., \& Rumbekwan, M. (2020). Political Reforms And The Role Of Parliament In Promoting Good Governance Through The Integration Of Religious Views In National Politics. Talent Development \& Excellence, 12(1), 3324-3330. Google Scholar

Lewis, B. (2014). The Jews Of Islam: Updated Edition (Vol. 86). Princeton University Press. Google Scholar

Mietzner, M. (2018). Fighting Illiberalism With Illiberalism: Islamist Populism And Democratic Deconsolidation In Indonesia. Pacific Affairs, 91(2), 261-282. Google Scholar

Movanita, A. N. K. (2017). Hti Resmi Dibubarkan Pemerintah. Kompas. Com, Nd Accessed July, 19. Google Scholar

Mudhoffir, A. M., Yasih, D. W. P., \& Hakim, L. (2017). Populisme Islam Dan Tantangan Demokrasi Di Indonesia. Prisma, 36(3), 48-59. Google Scholar

Muslim, G., \& Muslim, B. A. D. (2013). Mahmood Mamdani. Political Islam: A Critical Reader, 109. Google Scholar

Nasution, L. (2020). Hak Kebebasan Berpendapat Dan Berekspresi Dalam Ruang Publik Di Era Digital. 'Adalah, 4(3). Google Scholar

Power, T. P. (2018). Jokowi's Authoritarian Turn And Indonesia's Democratic Decline. Bulletin Of Indonesian Economic Studies, 54(3), 307-338. Google Scholar

Price, D. H. (2016). Cold War Anthropology: The Cia, The Pentagon, And The Growth Of Dual Use Anthropology. Duke University Press. Google Scholar

Robingatun, R. (2017). Radikalisme Islam Dan Ancaman Kebangsaan. Empirisma: Jurnal Pemikiran Dan Kebudayaan Islam, 26(1). Google Scholar 
Tomsa, D. (2017). Indonesia In 2016: Jokowi Consolidates Power. Southeast Asian Affairs, 149-162. Google Scholar

Usman, S., Qodir, Z., \& Hasse, J. (2014). Radikalisme Agama Di Indonesia. Yogyakarta: Pustaka Pelajar. Google Scholar

Warburton, E., \& Aspinall, E. (2017). Indonesian Democracy: From Stagnation To Regression? The Strategist, 17. Google Scholar

\section{Copyright holder :}

Muhammad Naufan Rizqullah (2021)

First publication right :

Journal Syntax Admiration

This article is licensed under:

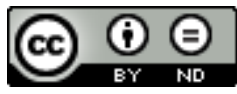

